DE DE GRUYTER OPEN

UNIVERSITATIS COMENIANAE (BRATISLAVA)

ISSN 1339-9802 (online)

\title{
BIOLEACHING OF ARSENIC AND ANTIMONY FROM MINING WASTE
}

\author{
Slavomír Čerňanský ${ }^{1}$, Alexandra Šimonovičová ${ }^{2}$, \\ Jana Juhásová ${ }^{1} \&$ Milan Semerád ${ }^{1}$ \\ ${ }^{1}$ Department of Environmental Ecology, ${ }^{2}$ Department of Soil Science, Faculty of Natural Sciences, \\ Comenius University in Bratislava, Mlynská dolina, Ilkovičova 6, 84215 Bratislava, Slovak Republic \\ Corresponding author: Slavomir Čerňanský (e-mail: cernanskys@fns.uniba.sk)
}

\begin{abstract}
This paper is a contribution to quantification of bio-leached arsenic and antimony from mining waste collected from impoundment in Slovinky (Slovakia). Autochtonous fungal strain Aspergillus niger was used in all bioleaching experiments. The contents of arsenic and antimony in two different samples from the impoundment were 294.7 and $328.2 \mathrm{mg} . \mathrm{kg}^{-1}$ As and 225.3 and $285.7 \mathrm{mg} . \mathrm{kg}^{-1} \mathrm{Sb}$, respectively. After 21-day cultivation of Aspergillus niger on such contaminated substrates, this strain was capable to bioleach, bioaccumulate and biovolatilize both toxic elements.
\end{abstract}

Key words: Slovinky, arsenic, antimony, bioleaching, microscopic filamentous fungi, biovolatilization, bioaccumulation

Recommended form of citation: Čerňanský, S., Šimonovičová, A., Juhásová, J. \& Semerád, M., 2016. Bioleaching of Arsenic and Antimony from Mining Waste. Acta Environ. Univ. Comenianae (Bratislava). 24(1): 5-9. DOI: 10.1515/aeuc-2016-0001

\section{INTRODUCTION}

Microorganisms and their metabolic processes are very important parts of biogeochemical cycles of chemical elements. They significantly affect mobility, toxicity, bioavailability a solubility of potentially toxic metals and metalloids in the environment (FAWCETT et al. 2015). Balance between mobility and immobilization of chemical elements, including arsenic and antimony, is affected mainly by microorganisms, their surrounding environment and physic-chemical conditions of this environment. The mine tailings of abandoned mines contain high levels of various toxic metals and metalloids such as arsenic and antimony, which are accumulated in soils, sediments and vegetation (LEE et al. 2011). The arsenic and antimony contents in mine tailings are known to be higher than their contents in contaminated soils (WANG \& MULLIGAN 2009). There are many abandoned mining sites, tailing impoundments and waste piles in Slovakia (JURKOVIČ et al. 2011, 2012; HILLER et al. 2012; То́тH et al. 2013). One of such highly contaminated sites by arsenic and antimony is the tailing 
impoundment Slovinky (Slovakia). To remove various toxic metals from highly metal(loid) contaminated substrates, bioremediation techniques have been introduced and used (NARESHKUMAR \& NAGENDRAN 2008). To microbial processes increasing mobility of chemical elements in the environment belongs bioleaching of metals and metalloids by bacteria, yeasts and microscopic filamentous fungi, production of chelates mediated by microbial metabolites and siderophores and alkylation (especially methylation) of metals and metalloids followed by their volatilization into the atmosphere (GADD 2004). Bioleaching of metal(loid)s by microscopic filamentous fungi and yeasts is mainly due to heterotrophic metabolism of microorganisms. Among several mechanisms of bioleaching by heterotrophic microorganisms, production and excretion of organic acids by microorganisms into the surrounding environment is very important. Although, bioleaching increases and accelerate releasing of metals and metalloids from rocks, minerals and other solid substrates, evolved citrate and oxalate anions can produce stabile and hardly soluble complexes with various chemical elements leading to immobilization of such elements (FRANCIS et al. 1992).

The aim of the study was to quantify processes of bioleaching, bioaccumulation and biovolatilization of arsenic and antimony by microscopic fungus Aspergillus niger.

\section{MATERIAL AND METHODS}

The solid material containing high levels of arsenic and antimony collected from the Slovinky tailing impoundment was used for experiments. All samples were collected using standard methods (SOJÁK et al. 2002). The impoundment material was collected from two different sampling points (S1 and S2) from the depth of $20 \mathrm{~cm}$ using hand shovel. Each sample was stored in plastic bags under $4{ }^{\circ} \mathrm{C}$ (portable refrigerators were used) in the dark. The samples were air-dried and sieved $(0.1 \mathrm{~mm})$ under laboratory conditions. All experiments were carried out in $250 \mathrm{ml}$ conic flasks with addition of 1, 10 and $30 \mathrm{~g}$ of the impoundment material, $5 \mathrm{ml}$ suspension of spores of microscopic filamentous fungus Aspergillus niger and $45 \mathrm{ml}$ of Sabouraud liquid medium (HiMedia, Mumbai, India). Used A. niger strain was isolated from the soil occurred in the farm in Kuwait with highly alkaline $\mathrm{pH}$ value reaching 8.49. After 15-day cultivation, fungal biomass was separated from the growth medium, washed by distilled water and dried at $40{ }^{\circ} \mathrm{C}$ for 5 days to reach constant weight. Residual solid material after cultivation was filtered using filter paper Whatman No. 1 and dried similarly as fungal biomass. Residual growth medium was transferred to volumetric flasks and treated by adding of $5 \mathrm{ml}$ of concentrated $\mathrm{HNO}_{3}$ to stabilize arsenic and antimony in the solution and as a prevention of re-growth of A. niger. There were three replicated runs for each experiment. Non-inoculated controls containing distilled water and desired amount of impoundment material were prepared to determine background volatilization fluxes of arsenic and antimony. Fungal controls were cultivated in the absence of impoundment material. The biomass, culture medium and residual solid material were analyzed for total arsenic and antimony concentrations by HG AAS (hydride generation atomic absorption spectrometry).

\section{RESULTS AND DISCUSSION}

The results of bioleaching of the impoundment solid material are shown in Tabs. 1-3. The original concentration of arsenic and antimony in the samples collected from the impoundment were as follows: S1 and S2 - 294.7 and $328.2 \mathrm{mg} \cdot \mathrm{kg}^{-1}$ As and 225.3 and $285.7 \mathrm{mg} \cdot \mathrm{kg}^{-1} \mathrm{Sb}$, respectively. Total balance of released arsenic and antimony from these two types of substrates consists of leached amount of arsenic and antimony into the growth medium, accumulated amount of arsenic and antimony in fungal biomass, contents of arsenic and antimony in residual substrates and volatilized amounts of arsenic and antimony. The results of volatilized amounts of arsenic and antimony were 
calculated as the difference between the content of total arsenic and antimony before cultivation and the sum of arsenic and antimony in the fungal biomass, growth medium and residual solid substrate. According to obtained results, it can be stated that the A. niger strain was capable to mobilize arsenic and antimony from the impoundment material. The released amount of arsenic was significantly higher than the amount of antimony. The highest calculated amounts of arsenic and antimony were released using $1 \mathrm{~g}$ of substrate (up to $33 \%$ for arsenic). The efficiency of bioleaching, expressed by percentage of total amounts of arsenic and antimony released from original substrates, decreased in case of arsenic with the weight of solid substrate. But in case of antimony, it seems that the weight of substrates is not critical (total amounts of antimony released from substrates at three different weights of substrates were very similar ranging from 10.8 to $13.7 \%$.

Tab. 1: Bioleaching of impoundment material from arsenic- and antimony- contaminated substrates (1 g) (Slovinky, Slovakia) by Aspergillus niger $(\mathrm{n}=3)$

\begin{tabular}{lcccc}
\hline Sample & $\begin{array}{c}\text { Content of As/Sb in } \\
\text { medium after } \\
\text { cultivation } \\
{[\boldsymbol{\mu g}]}\end{array}$ & $\begin{array}{c}\text { Content of As/Sb in } \\
\text { biomass } \\
{[\boldsymbol{\mu g}]}\end{array}$ & $\begin{array}{c}\text { Volatilized } \\
\text { amount of As/Sb } \\
{[\boldsymbol{\mu g}]}\end{array}$ & $\begin{array}{c}\text { Total amount of } \\
\mathbf{A s} / \text { Sb released from } \\
\text { substrates } \\
{[\boldsymbol{\%}]}\end{array}$ \\
\hline $\mathrm{S} 1$ 1 g/As & 20.5 & 21.1 & 33.3 & 25.4 \\
$\mathrm{~S} 21 \mathrm{~g} / \mathrm{As}$ & 33.8 & 14.4 & 49.2 & 33.0 \\
$\mathrm{~S} 1 \mathrm{~g} / \mathrm{Sb}$ & 9.0 & 15.7 & 19.7 & 13.6 \\
$\mathrm{~S} 21 \mathrm{~g} / \mathrm{Sb}$ & 6.4 & 13.5 & 11.0 & 13.7 \\
\hline
\end{tabular}

Comments: S1, S2 - different substrates collected from the tailing impoundment Slovinky, concentrations of As and Sb in S1 and $\mathrm{S} 2$ were 294.7 and $328.2 \mathrm{mg} \cdot \mathrm{kg}^{-1}$ As and 225.3 and $285.7 \mathrm{mg} \cdot \mathrm{kg}^{-1} \mathrm{Sb}$, respectively; $1 \mathrm{~g}$ - amount of added impoundment substrate

Bioleaching of arsenic and antimony in comparison with ILYAS et al. (2012) is markedly lower. They reached $60 \%$ leaching of arsenic from the solid substrates by the A. niger KBS4 strain. There is lack of information on fungal bioleaching of arsenic and antimony in the recent literature. Slightly more information can be found on biovolatilization of arsenic and antimony by microscopic filamentous fungi. It seems that microscopic filamentous fungi are capable to grow on even extremely high concentrations of arsenic and antimony (SRIVASTAVA et al. 2011) and subsequently they are able to biovolatilize high amounts of arsenic and antimony. This metabolic process of biomethylation of arsenic and antimony followed by volatilization of these elements into the atmosphere can significantly affect biogeochemical cycles of arsenic and antimony. Moreover, biomethylation and biovolatilization towards with bioleaching of arsenic and antimony could be a promising alternative for bioremediation of arsenic- and antimony- contaminated sites.

Tab. 2: Bioleaching of impoundment material from arsenic- and antimony- contaminated substrates (10 g) (Slovinky, Slovakia) by Aspergillus niger $(\mathrm{n}=3)$

\begin{tabular}{lcccc}
\hline Sample & $\begin{array}{c}\text { Content of As/Sb in } \\
\text { medium after } \\
\text { cultivation }[\boldsymbol{\mu g}]\end{array}$ & $\begin{array}{c}\text { Content of As/Sb } \\
\text { in biomass } \\
{[\boldsymbol{\mu g}]}\end{array}$ & $\begin{array}{c}\text { Volatilized } \\
\text { amount of As/Sb }\end{array}$ & $\begin{array}{c}\text { Total amount of As/Sb } \\
\text { released from substrates } \\
{[\boldsymbol{\mu} \mathbf{g}]}\end{array}$ \\
\hline S1 10g/As & 54.7 & 27.7 & 46.0 & 4.4 \\
S2 10g/As & 55.8 & 17.5 & 194.0 & 9.0 \\
S1 10g/Sb & 9.0 & 15.7 & 19.7 & 13.7 \\
S2 10g/Sb & 6.4 & 40.4 & 11.0 & 13.7 \\
\hline
\end{tabular}

Comments: S1, S2 - different substrates collected from the tailing impoundment Slovinky, concentrations of As and Sb in S1 and $\mathrm{S} 2$ were 294.7 and $328.2 \mathrm{mg} . \mathrm{kg}^{-1} \mathrm{As}$ and 225.3 and $285.7 \mathrm{mg} . \mathrm{kg}^{-1} \mathrm{Sb}$, respectively; $10 \mathrm{~g}$ - amount of added impoundment substrate 
Tab. 3: Bioleaching of impoundment material from arsenic- and antimony- contaminated substrates (30 g) (Slovinky, Slovakia) by Aspergillus niger $(\mathrm{n}=3)$

\begin{tabular}{lcccc}
\hline Sample & $\begin{array}{c}\text { Content of As/Sb in } \\
\text { medium after } \\
\text { cultivation } \\
{[\mu \mathrm{g}]}\end{array}$ & $\begin{array}{c}\text { Content of As/Sb } \\
\text { in biomass } \\
{[\boldsymbol{\mu g}]}\end{array}$ & $\begin{array}{c}\text { Volatilized } \\
\text { amount of } \\
\mathbf{A s} / \mathbf{S b} \\
{[\boldsymbol{\mu g}]}\end{array}$ & $\begin{array}{c}\text { Total amount of As/Sb } \\
\text { released from } \\
\text { substrates }[\boldsymbol{\mu g}]\end{array}$ \\
\hline $\mathrm{S} 130 \mathrm{~g} / \mathrm{As}$ & 10.3 & 6.8 & 525.7 & 6.2 \\
$\mathrm{~S} 230 \mathrm{~g} / \mathrm{As}$ & 3.3 & 5.3 & 498.9 & 5.7 \\
$\mathrm{~S} 130 \mathrm{~g} / \mathrm{Sb}$ & 20.7 & 19.5 & 672.5 & 10.8 \\
$\mathrm{~S} 230 \mathrm{~g} / \mathrm{Sb}$ & 17.2 & 14.3 & 792.5 & 12.2 \\
\hline
\end{tabular}

Comments: S1, S2 - different substrates collected from the tailing impoundment Slovinky, concentrations of As and Sb in S1 and S2 were 294.7 and $328.2 \mathrm{mg} . \mathrm{kg}^{-1}$ As and 225.3 and $285.7 \mathrm{mg} \cdot \mathrm{kg}^{-1} \mathrm{Sb}$, respectively; $30 \mathrm{~g}$ - amount of added impoundment substrate

\section{CONCLUSION}

Understanding of processes, which affected transformations of potentially toxic elements by microorganisms allows not only their effective application in removal of various potentially toxic elements including arsenic and antimony from highly contaminated substrates but also their influence on the distribution of such elements in the nature and their effects on human health.

\section{ACKNOWLEDGEMENTS}

This work was funded by the grant of Ministry of Education, Science, Research and Sport of the Slovak Republic VEGA 1/0098/14, VEGA /1/0482/15 and this contribution is also result of the project implementation ITMS 26240120014 "Center of excellence for protection and use of landscape and for biodiversity" supported by the ERDF.

\section{REFERENCES}

FAwCETT S. E., JAMIESON H. E., KIRK NORDSTROM D. \& Blaine MCCLESKey R. 2015. Arsenic and antimony geochemistry of mine wastes, associated waters and sediments at the Giant Mine, Yellowknife, Northwest Territories, Canada. Appl. Geochem., doi: http://dx.doi.org/10.1016/j.apgeochem. 2014.12.012.

FRANCIS A. J., DODGE C. J. \& GILLOW J. B. 1992. Biodegradation of metal citrate complexes and implications for toxic metal mobility. Nature 356: 140-142.

GADD G. M. 2004. Microbial influence on metal mobility and application for bioremediation. Geoderma 122: 109-119.

Hiller E., Lalinská-Voleková B., Chovan M., Jurkovič L', Klimko T., JankUlár M., Hovorič R., ŠOTTNíK P., FLAKOVÁ R., ŽENIŠOVÁ Z. \& ONDREJKOVÁ I. 2012. Arsenic and antimony contamination of waters, stream sediments and soils in the vicinity of abandoned antimony mines in the Western Carpathians, Slovakia. Appl. Geochem. 27: 598-614.

ILYAS S., RUAN C., LEE J. C. \& BHATTI H. N. 2012. One step bioleaching of sulphide ore with low concentration of arsenic by Aspergillus niger and Taguchi Orthogonal Array Optimization. Biotechnol. Bioeng. 20: 923929.

Jurkovič, L., Hiller E., VeselskÁ V. \& PeŤKovÁ K. 2011. Arsenic concentrations in soils impacted by dam failure of coal-ash pond in Zemianske Kostolany, Slovakia. Environ. Contam. Tox. 86: 433-437.

Jurkovič, L., Šottník P., Lalinská-Voleková B., VozÁr J., Petrák M. \& Tóth R. 2012. Identifikácia environmentálnych rizík z antropogénnych sedimentov (Odkalisko-Slovinky). In: Sanační technologie 15, Pardubice. Sborník konference, Ekomonitor, 125-127.

LeE K. Y., Kim H. A., Lee B. T., Kim S. O., KwON Y. H. \& Kim K. W. 2011. A feasibility study on bioelectrokinetics for the removal of heavy metals from tailing soil. Environ. Geochem. Hlth 33: 3-11.

NARESHKUMAR R. \& NAGENDRAN R. 2008. Changes in nutrient profile of soil subjected to bioleaching for removal of heavy metals using Acidithiobacillus thiooxidans. J. Hazard. Mater. 156: 102-107. 
SojÁk L., Chmielewská E., Krištín J., Kubinec R. \& MÁtel J. 2002. Monitoring kontaminácie životného prostredia. Bratislava: publ. Comenius University in Bratislava, $143 \mathrm{p}$.

Srivastava P. K., Vaish A., Dwivedi S., Chakrabarty D., Singh N. \& Tripathi R. D. 2011. Biological removal of arsenic pollution by soil fungi. Sci. Total Environ. 409: 2430-2442.

Tóth R., Petrák M., Jurkovič L., Šottník P., VozÁr J. \& PeŤKová K. 2013. Odkaliská Markušovce a Slovinky - aplikácia metodického postupu pre hodnotenie odkaliskových sedimentov pochádzajúcich z úpravy rúd na modelových odkaliskách. Mineralia Slovaca. 45: 125-130.

WANG S. L. \& MULLIGAN C. N. 2009. Enhanced mobilization of arsenic and heavy metals from mine tailings by humic acid. Chemosphere. 74: 274-279. 